\title{
A Study on Evaluation of Alkaline and Acid Phosphatase Isozymes During Different Developmental Stages of New Breeding Lines and Races of Bombyx mori L Manjula A.C. and Keshamma E*
}

Department of Sericulture, Maharani Cluster University, Palace Road, Bengaluru, Karnataka

*Corresponding Author E-mail: keshamma.blr76@gmail.com

\begin{abstract}
Article Info

Volume 8, Issue 5

Page Number : 293-299

Publication Issue :

September-October-2021

Article History

Accepted : 20 Oct 2021

Published: 30 Oct 2021

It is interesting to note that different silkworm races reared in laboratory offer an important testing ground for the application of biochemical methods to taxonomic problems. Moreover, there is scarcity of knowledge on enzyme studies in new breeding lines and races of silkworm specially Bombyx mori L. Therefore, we designed the present study with the main goal to evaluate the activities of alkaline and acid phosphatases quantitatively during different developmental stages of new breeding lines and races viz. Kalimpong-A (KA), $\mathrm{B}_{18}$, Pure Mysore (PM), evolved $\mathrm{R}_{1}$ and $\mathrm{R}_{2}$ of Bombyx mori L. Quantitative estimations of in alkaline and acid phosphatases were expressed in terms of enzyme activity. Alkaline and acid phosphatase activities during the different developmental stages of $\mathrm{KA}, \mathrm{NB}_{18}, \mathrm{PM}$, evolved $\mathrm{R}_{1} \& \mathrm{R}_{2}$ races were determined using Sodium-1 naphthahyl phosphate as a substrate following the dye-coupling method. The assay mixture included $2 \mathrm{ml}$ of substrate and $0.2 \mathrm{ml}$ of enzyme extract and incubation was made for 30 minutes at $25^{\circ} \mathrm{C}$. The reaction was stopped by adding $2 \mathrm{ml}$ of post coupling solution ( 5 parts of $4 \%$ sodium dodecyl sulphate and 2 parts of $0.2 \%$ Fast red TR salt) and colorimetric determination were made at $540 \mathrm{~nm}$. Results illustrated that the activity of phosphatases was found to be different and high activity was found in the larval stage, which is feeding stage followed by pupae.
\end{abstract}

Keywords : Bombyx mori L, Alkaline phosphatase, Acid phosphatase, Larva stage

\section{INTRODUCTION}

Every change in the enzyme pattern during development can be directly determined by genetic function. This reflects the change in the metabolism of the developing organism [1]. Analysis of different genetic enzyme systems have shown different regulation of genetic activation during metabolic changes. Isozymes can be viewed as ideal gene products for studying gene expression patterns during development. They provide a potential tool and biochemical index to assess genetic variability in natural populations [2-5]. These studies have often been used to follow evolutionary variations in different enzyme patterns, as well as when comparing species [6]. Gene enzyme systems in Drosophila and a few other animals drew the attention of several workers

Copyright: (C) the author(s), publisher and licensee Technoscience Academy. This is an open-access article distributed under the terms of the Creative Commons Attribution Non-Commercial License, which permits unrestricted non-commercial use, distribution, and reproduction in any medium, provided the original work is properly cited 
and the early work on biochemical basis of eye colour mutant in Drosophila notably by during 1930's played a crucial role in establishing the relationships between genes and enzymes [6]. The isoenzymes present during the different stages of development can be studied in two ways. One is to understand the different effects of genes during development and the other is to compare the manifestation of homologous enzymes during the stages of development.

Nakamura first reported the occurrence of phosphatases in silkworm Bombyx mori L in 1940 [7]. In insects' attempts have been made to localise acid and alkaline phosphatases in particular tissues [8,9]. Alkaline phosphatase is located in cells that are active in the synthesis of fibrous proteins and in the malpighian tubules [10]. Shridhara and Bhat showed a definite relationship between the changes in the alkaline and acid phosphatases with growth and moulting of the silkworm. Acid and alkaline phosphatases increase from hatching to spinning stage with a noticeable decrease at each moult. At the pupal stage alkaline phosphatase activity was absent but acid phosphatase activity was high [11]. Histochemical localizations of both acid and alkaline phosphatases in $B$. mori midgut were examined at the light microscopical level by Horie [12].

Nevertheless, there is scarcity of knowledge on enzyme studies in new breeding lines and races of silkworm specially Bombyx mori L signifying importance of work to be done in future in this prospective. Furthermore, it is interesting to note that different silkworm races reared in laboratory offer an important testing ground for the application of biochemical methods to taxonomic problems. With this background, we designed the present study with the main goal to evaluate the activities of alkaline and acid phosphatase isozymes quantitatively during different developmental stages of new breeding lines and races of Bombyx mori L.

\section{METHODS AND MATERIAL}

\subsection{Silkworm Varieties and Rearing}

The pure races of bivoltine Kalimpong-A (KA) spinning oval white cocoons, New Bivoltine-18 ( $\left.\mathrm{NB}_{18}\right)$ spinning dumbbell white cocoons and multivoltine Pure Mysore (PM) spinning pointed yellow cocoons of mulberry silkworm Bombyx mori L. were selected for the present breeding programme. These races were obtained from their respective seed areas and are reared in cytogenetics laboratory, Jnana Bharathi, Bangalore University.

The disease free layings were prepared as described by Krishnaswamy, and were incubated at $25^{\circ} \mathrm{C}$ and relative humidity of $60-70 \%$. On 8th day composite layings were prepared (10-20 layings were prepared 100-200 eggs were collected from each laying). The hatched worms were reared according to the method described by Krishnaswamy [13]. MS variety of mulberry leaves were used in rearing. The worms were reared in mass up to III instar, after III moult 300 worms were collected in three replicates in order to evaluate the rearing performance. Standard temperature and humidity were maintained in the rearing house.

\subsection{Breeding}

Single and three way crosses were made by using the above said three races. The first single cross involved KA females and PM males. The second single cross involved $\mathrm{NB}_{18}$ females and $\mathrm{PM}$ males. During the course of breeding selection was made at the egg, larva, pupa and cocoon stages to fix the desirable traits. F5 progenies of the respective crosses were back crossed to their respective bivoltine males to improve commercial characters.

\subsection{Evolutions of New Lines R1 and R2}

Females of KA and NB18 were crossed with males of $\mathrm{PM}$. The composite layings of F1 hybrid were brushed and reared under standard laboratory conditions. The selection parameters explained earlier were applied to choose the seed cocoons for the preparation of F2 layings. The replicates showing higher pupation rate were selected for intra family selection of cocoons. Further, segregation with respect to cocoon colour and built was noticed. Only white oval in case of KAxPM and dumbbell white in case of $\mathrm{NB}_{18} \mathrm{xPM}$ qualifying the parameter of selection were choosen for breeding in subsequent generations. The females of F5 were backcrossed to the males of KA and NB18 respectively in both the lines and reared up to 11 generations. At the end of the 11th generation the lines $R_{1}$ and $R_{2}$ were extracted with higher ERR than their respective better parents, with shorter larval period and with moderate cocoon productivity character in case of $R_{1}$ and $R_{2}$. 


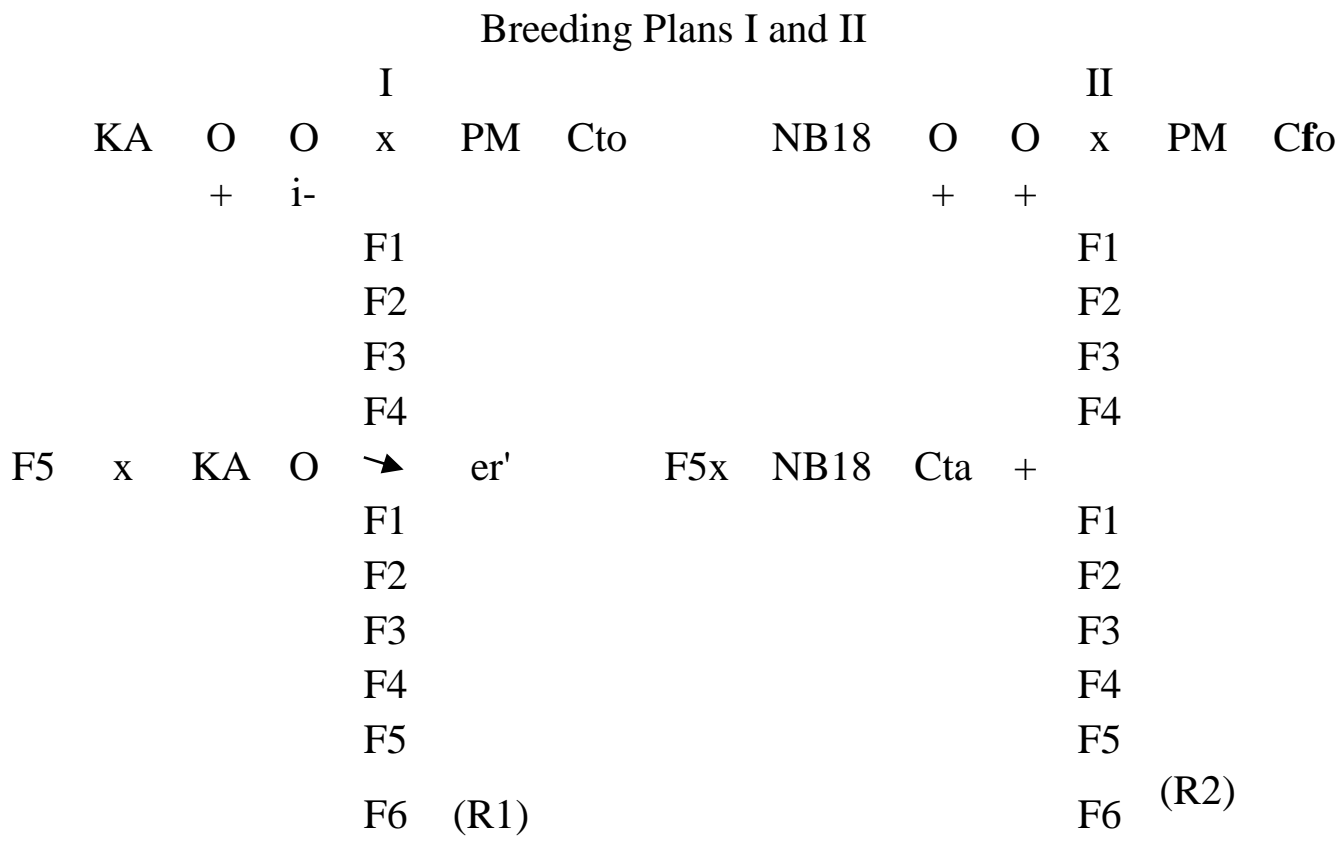

\subsection{Preparation of enzyme extract}

The different developmental stages such as 1st day, 5th day and 9th day eggs, five larval instars (I, II, III, IV, and V instars), early, middle and late stages of male and female pupae, male moths before and after copulation. Female moths before and after egg laying of bivoltine races $\mathrm{KA}, \mathrm{NB}_{18}$, multivoltine race $\mathrm{PM}$ and evolved races race-1 $\left(\mathrm{R}_{1}\right)$ and Race- $2\left(\mathrm{R}_{2}\right)$ were selected.

\subsection{Assay of Alkaline and Acid Phosphatases}

Alkaline and acid phosphatase activity were measured using Sodium-1 naphthahyl phosphate as a substrate following the dye-coupling method of MacIntyre. The assay mixture included $2 \mathrm{ml}$ of substrate and $0.2 \mathrm{ml}$ of enzyme extract and incubation was made for 30 minutes at $25^{\circ} \mathrm{c}$. The reaction was stopped by adding $2 \mathrm{ml}$ of post coupling solution (5 parts of $4 \%$ sodium dodecyl sulphate and 2 parts of $0.2 \%$ Fast red TR salt) and colorimetric determination were made at $540 \mathrm{~nm}$. [14].

\section{RESULTS AND DISCUSSION}

The quantitative estimations in alkaline and acid phosphatases are expressed in terms of enzyme activity during different developmental stages of the races KA, $\mathrm{NB}_{18}, \mathrm{PM}, \mathrm{R}_{1}$ and $\mathrm{R}_{2}$. These two enzymes are present in very low concentrations in eggs and adults but a very high enzyme activity was observed in IV and V instar larvae of all the races. APH and ACPH activity declines in pupae and adult stages. The activity was found to be high in KA followed by $\mathrm{NB}_{18}, \mathrm{PM}, \mathrm{R}_{1}$ and $\mathrm{R}_{2}$ (Figures $1-8)$.

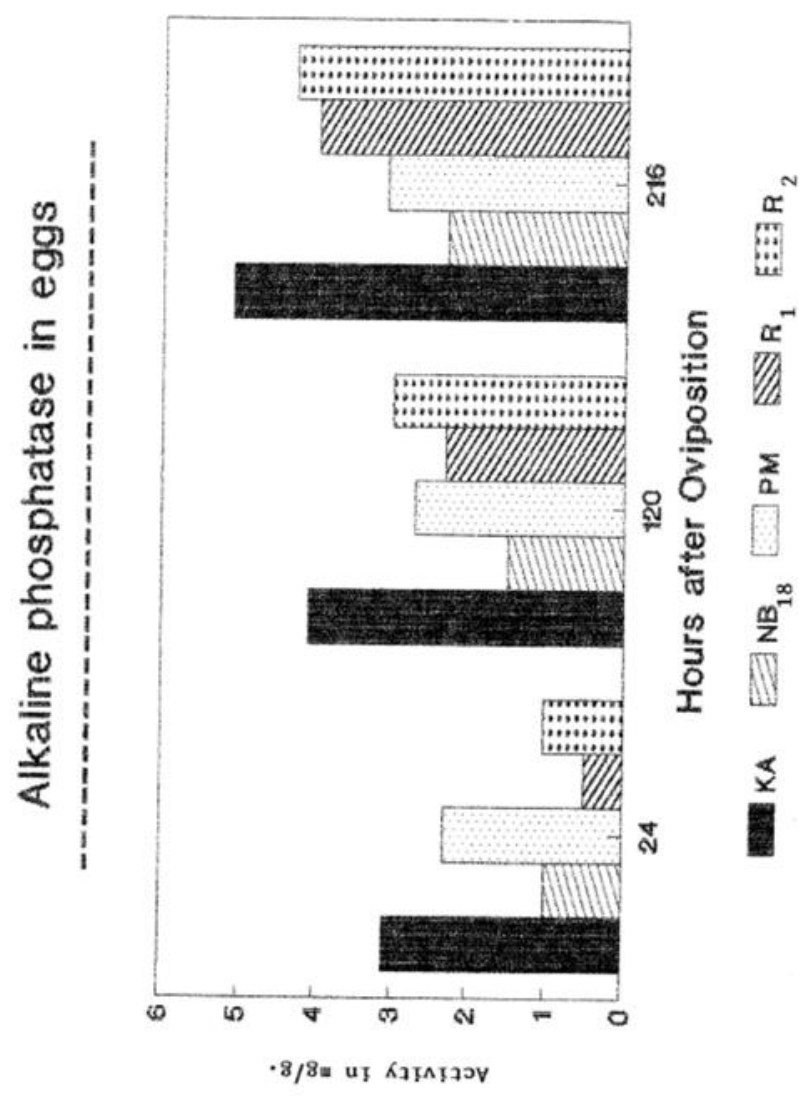

Figure 1 


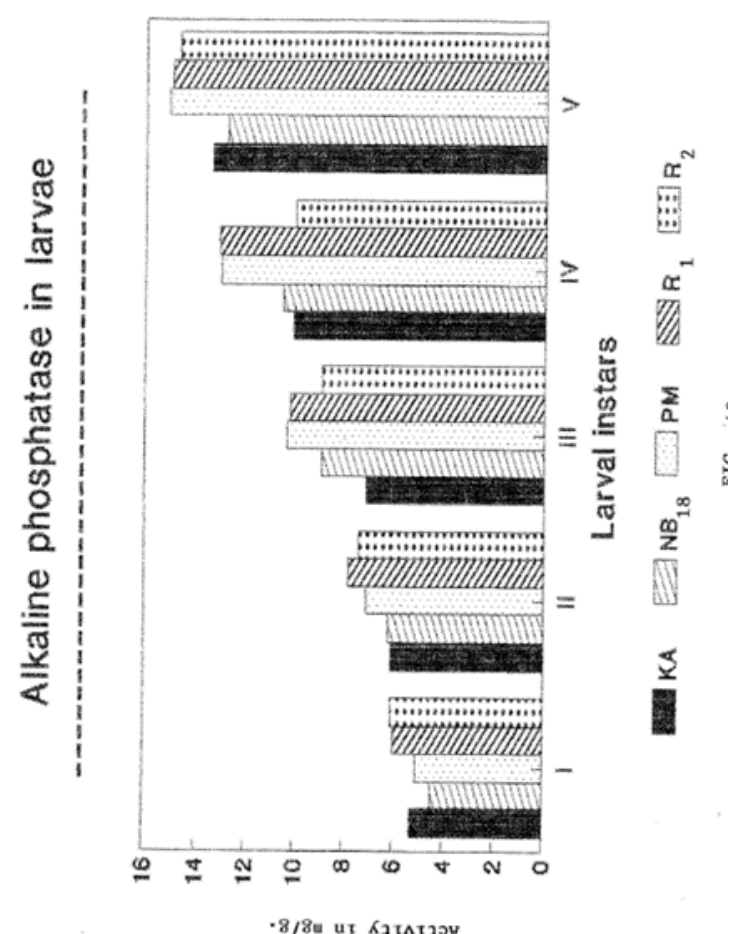

Figure 2

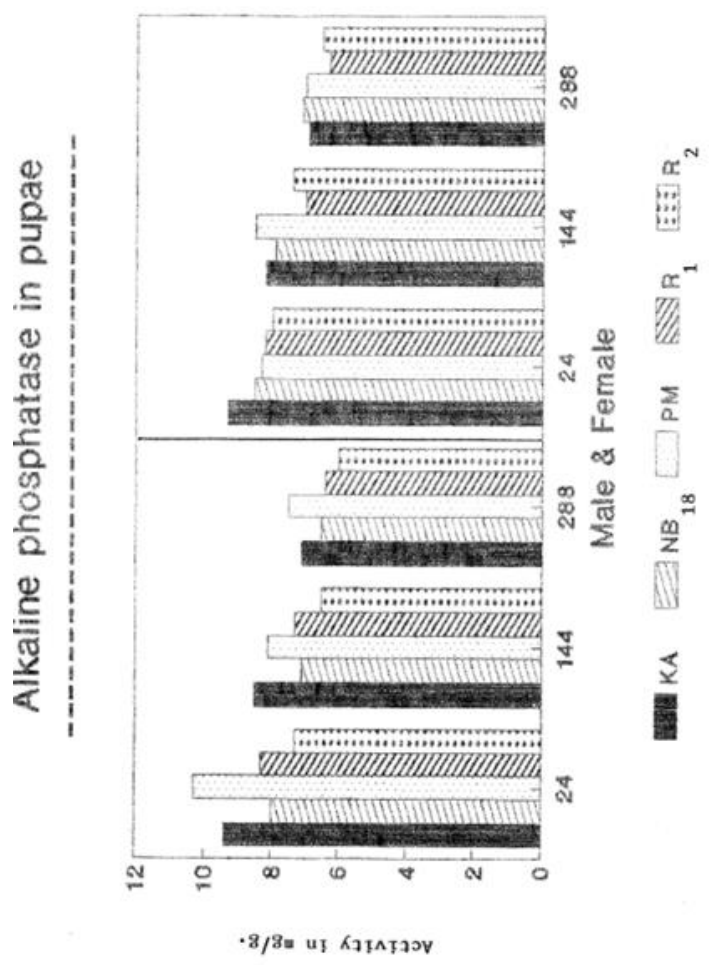

Figure 3

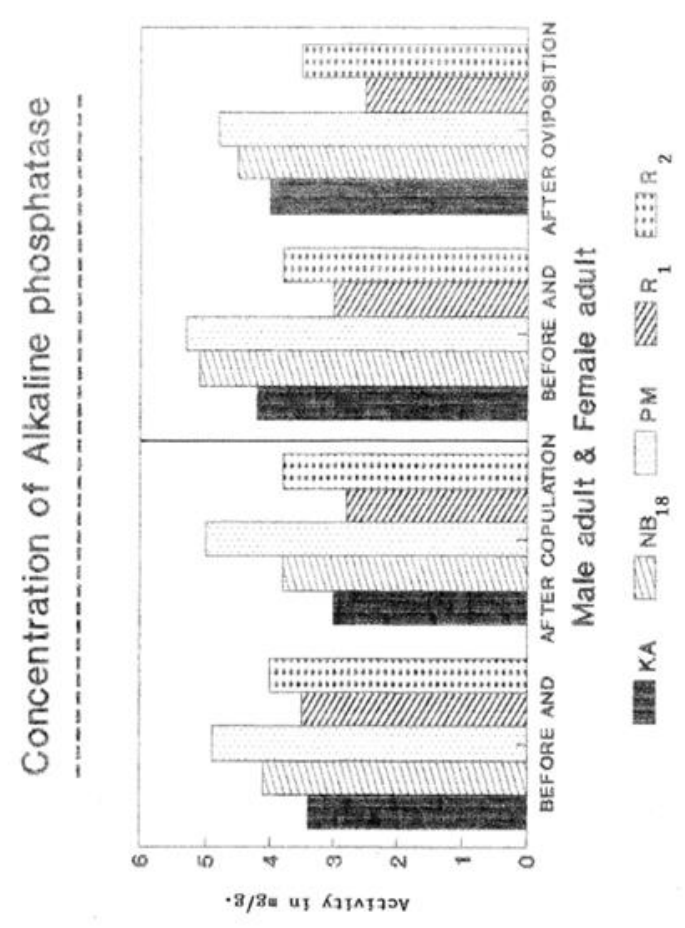

Figure 4

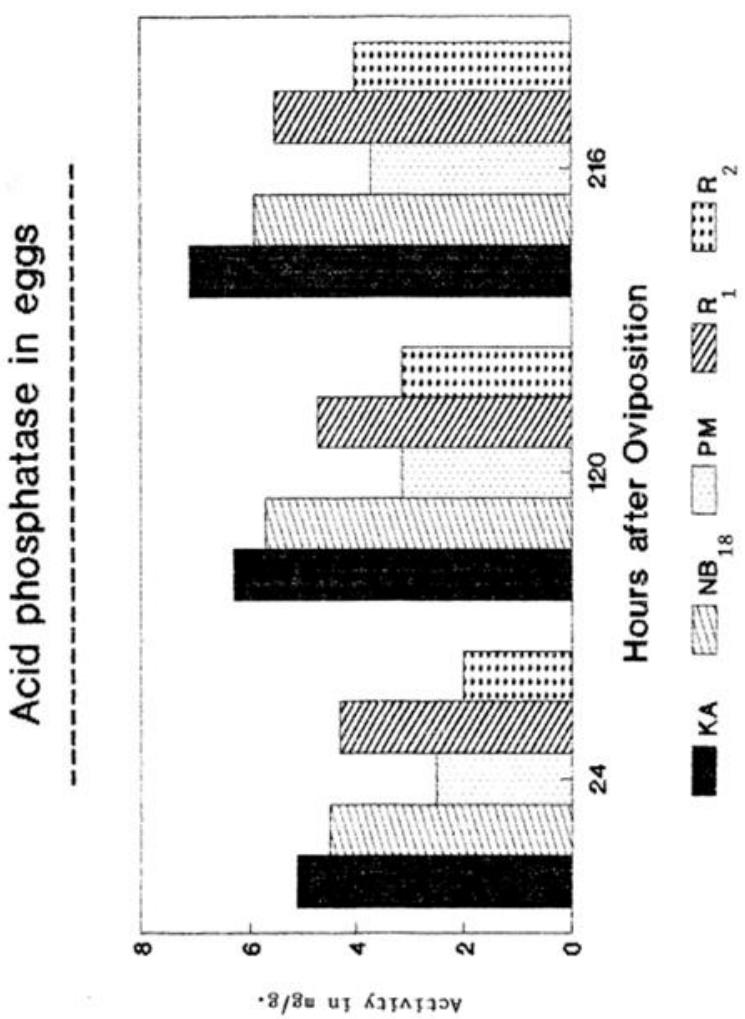

Figure 5 


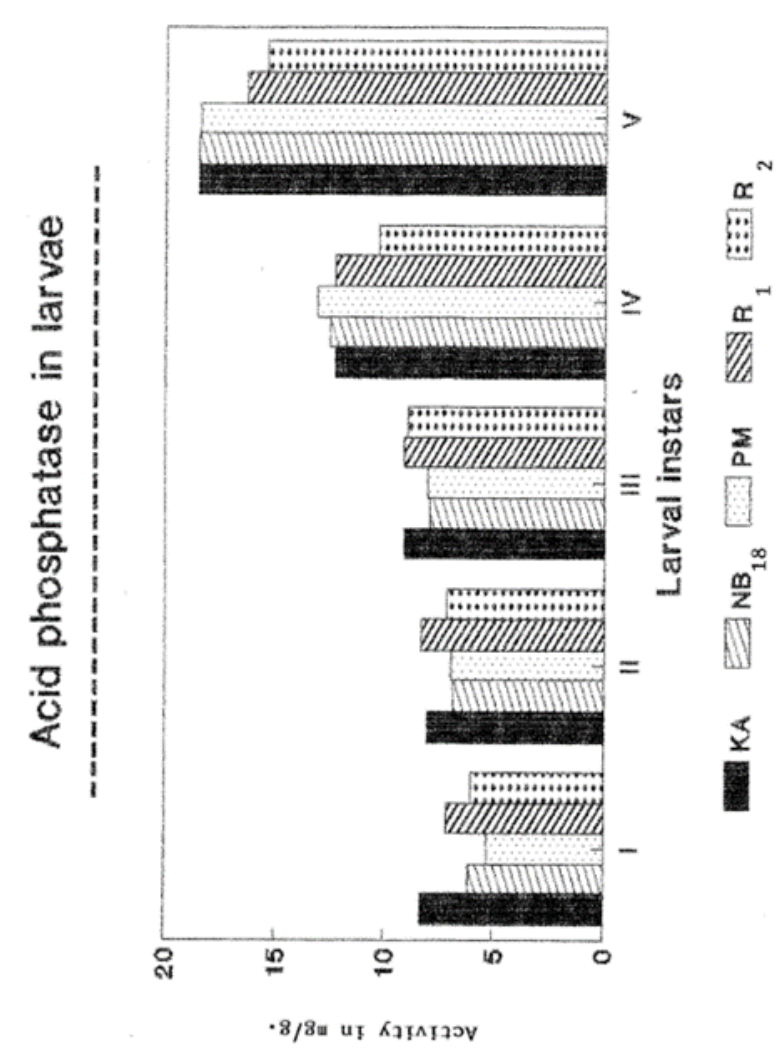

Figure 6

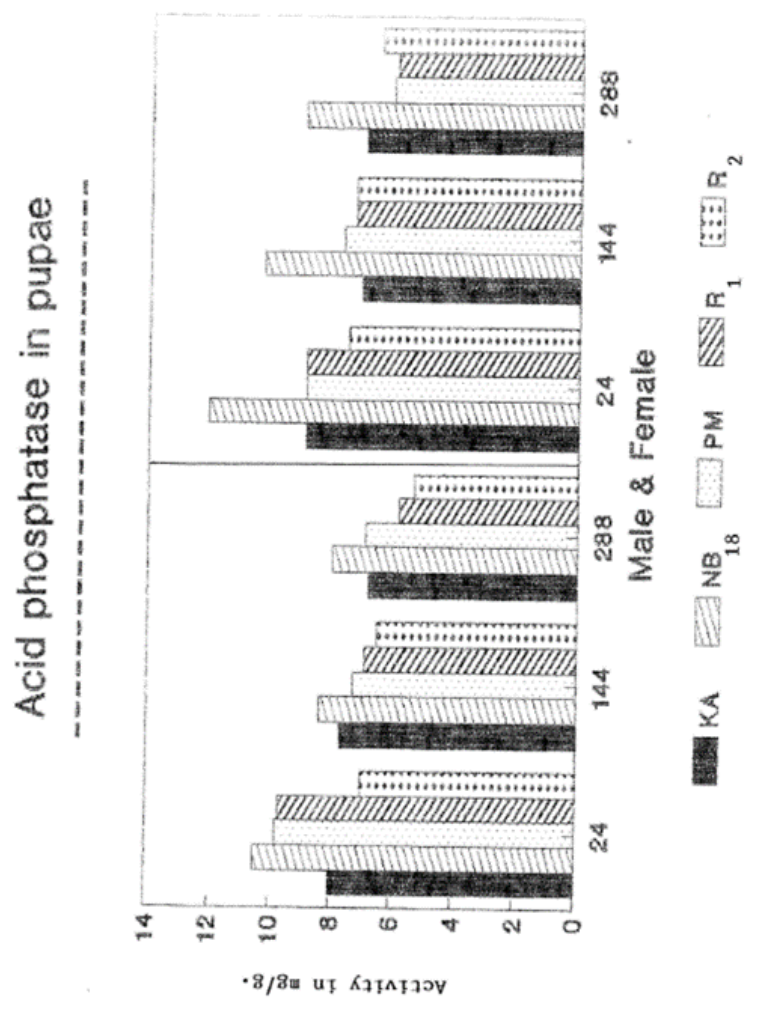

Figure 7

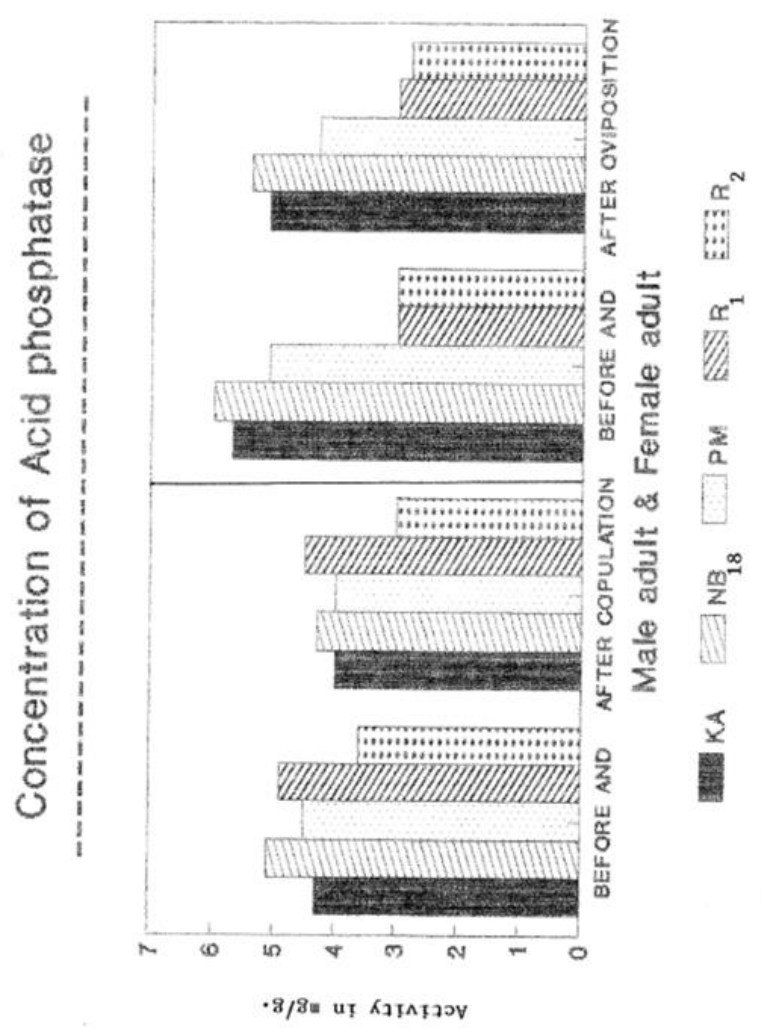

Figure 8

The occurrence of phosphatases in silkworm Bombyx mori were first reported by Nakamura in the year 1940 . Later many workers studied these enzymes $[8,9]$. The results of activities of alkaline and acid phosphatases obtained in our study showed increased activity from eggs to $\mathrm{V}$ instar larvae and it was decreased in pupae and adults. These findings were in accordance with other workers also [11,15,]. The high activity of phosphatase during larval stage is due to the hydrolysis, histogenesis, cell differentiation and transformation. Low activity of the phosphatase in pupae and adult is because of the process of hydrolysis from $\mathrm{V}$ instar larval stage to pupae. This is also studied in Lepidopterous [16]. On the basis of above studies, it is suggested that during metamorphosis midgut tissues undergo gradual degradation under the presence of hydrolases like acid and alkaline phosphatases which are originated from lysosymes in degenerated cells. This is also studied in Anthereae myliltta, tasar silkworm by Sinha et al where $\mathrm{ACPH}$ activity was maximum in $3 \mathrm{rd}$ instar and decreased in spinning stage. APH activity was minimum and decrease again in spinning stage [17].

The present results also agree with the findings of Hedge and Krishnamurthy where the activity of APH 
and $\mathrm{ACPH}$ was low in eggs but increased gradually towards $\mathrm{V}$ instar larvae and it was still decreased in later stages [18].The phosphatases are mainly concerned with the digestion of the ingested food and degradation of the cellular substances [19].The fact that the silkworm egg shows neither digestive activity nor degradation of cellular substances accounts for low activity of APH and ACPH in the eggs. Further, the larval stage is the only feeding stage in silkworm after which feeding stops. In the pupal and moth stages there is a lot of resorption of cells and tissues. Hence high phosphatase activity is seen in larval stage which gradually declines in later stages. The genes which control this mechanism are active in the larval stages and are less active in pupal and get inhibited in adult stage.

\section{IV.CONCLUSION}

In conclusion, the activity of phosphatases was found to be different and high activity was found in the larval stage, which is feeding stage followed by pupae. They are mostly present in the lysozymes of $\mathrm{NB}_{18}$ hybrids $\mathrm{R}_{1}, \mathrm{R}_{2}$ and $\mathrm{PM}$.

\section{REFERENCES}

[1] Pasteur, N., \& Kastritsis, C. D. (1971). Developmental studies in Drosophila: I. Acid phosphatases, esterases, and other proteins in organs and whole-fly homogenates during development of D. pseudoobscura. Developmental biology, 26(4), 525-536.

[2] Ayala, F. J., Tracey, M. L., Barr, L. G., McDonald, J. F., \& Pérez-Salas, S. (1974a). Genetic variation in natural populations of five Drosophila species and the hypothesis of the selective neutrality of protein polymorphisms. Genetics, 77(2), 343-384.

[3] Ayala, F. J., Tracey, M. L., Barr, L. G., \& Ehrenfeld, J. G. (1974b). Genetic and reproductive differentiation of the subspecies, Drosophila equinoxialis caribbensis. Evolution, 24-41.
[4] McKenzie, J. A., \& Parsons, P. A. (1974). Microdifferentiation in a natural population of Drosophila melanogaster to alcohol in the environment. Genetics, 77(2), 385-394.

[5] Narang, S. (1980). Genetic variability in natural populations, evidence in support of the selectionist view. Experientia, 36(1), 50-51.

[6] Dickinson, V. J., \& Sullivan, D. T. (1975). Gene enzyme systems in Drosophila. Results and problems in cell differentiation. SpringerVerlag. Berlin. Heidelberg, New York, 6.

[7] Nakamura, I. (1940). The phosphorus metabolism during the growth of the animal. The behaviour of various phosphatases and compounds of Bornbyx rnori L. During growth. Mitt. Med. Acad. Kioto, 28: 387-416.

[8] Day, M.F. (1949). The distribution of alkaline phosphatases in insects. Anst. J. Sci. Res. 2 3141.

[9] Bradfield, J.R.J. (1951). Phosphatases and nucleic acids in silk glands. Cytochemical aspects of fibrillar in silk glands. Cytochemical aspects of fibrillar protein secretin. Quart. J. Mier. Sci. 92: 87-112.

[10] Drilhon, A. (1954). Etute electrophoretique des proteins de phemolymphe du Bombyx mori au cours de son cycle de croissance. C.R. Acad szr-: Paris, 238: 2543-2454.

[11] Sridhara S, Bhat J.V. (1963). Alkaline and acid phosphatases of the silkworm, Bombyx mori L. J Insect Physiol 9:693-701.

[12] Horie, Y. 1955. Alakline phosphatase in gut of silkworm larva. Jap. J. Appl. Ent. Zool., 20: 6874.

[13] Krishnaswamy, S. (1978). Improved techniques of bivoltine rearing, CSB Publication.

[14] Mac Intyre, R. (1971). Quantitative analysis of phosphatases Ind. J. of Exp. Biol., 17: 553.

[15] Drilhon, A. and Bunsel, R.F. (1945). Recherches sur les phosphatases d' insects. Bull. Soc. Chim. Biol. 27: 415-418. 
[16] Seong, S.I., Kobayashi, M. and Yoshitake, N. (1983). Activities of acid phoshpatase and nucleases during metamorphosis in the midgut of the silkworm Bombyx mori. J. Serie. Sci. Jpn. 52: 191-197.

[17] Sinha, A.K., Sinha, U.S.P., Shivaraju, K. and Sinha, S.S. (1991). Phosphatase activity in tasar silkworm Antheraea mylitta D. during its larval and pupal development. Indian J. Serie. 30, No. 1, 91-92.

[18] Hedge, S.N. and Krishnamurthy, N.B. (1976). Studies on the genetics of isozymes in the hybrids of Drosophila bipectinata complex. Proc. Dunn. Dobzh. Symp. Genet. Mysore, 9097.

[19] deDuve, C. (1963). The lysosyme concept Inciba foundation symposium on lysosymes (Ed) De Reuck, A.V.S. and M.P.I. Cameron. Little, Brown, Boston.

\section{Cite this article as :}

Manjula A. C., Keshamma E, "A Study on Evaluation of Alkaline and Acid Phosphatase Isozymes During Different Developmental Stages of New Breeding Lines and Races of Bombyx mori L ", International Journal of Scientific Research in Science, Engineering and Technology (IJSRSET), Online ISSN : 2394-4099, Print ISSN : 2395-1990, Volume 8 Issue 5, pp. 293-299, September-October 2021. Available at doi : https://doi.org/10.32628/IJSRSET218536

Journal URL : https://ijsrset.com/IJSRSET218536 